\title{
健康に及ぼす生活環境の影響
}

東 博文* 山中 隆夫*

\section{Effect of Life Environments Factors on Human Health}

\section{Hirofumi HIGASHI* and Takao YAMANAKA*}

The purpose of the present study is to examine whether or not one's life environment factors effect on his state of health. Data were gathered from those who took health examinations at a health care center during the period of June 3 to Sepetember 22, 1987. A total of 1200 males and females were surveyed. Of those only males $(\mathrm{N}=955)$ are singled out for detailed study. The analysis focuses upon examination of the relationship between the subjects' life habits (e.g. exercise habit, ocupation, etc.) and various health index scores obtained from clinical chek-ups of the subjects. The results include the followings:

1. Relationships were found between life habits (i.e. occupation, smoking, driving, and motorcycle riding) and various health indexes considered.

2. Greater deviation in blood sugar (at the time of starvation) was ovserved for those reqularly exercise for their health sake, whereas more of those without exercise habit tended to deviate with regard to heart-lung ratio, red blood cell count, and MCV.

3. Those who were considered working too hard showed significantly higher level of obesity and TG (triglyceride), but the number of deviants on these indexes were relatively small for them.

4. Greater deviation in cardiac funcution (i.e. RaV5) was observed for those having a concurrent job position.

5. A large proportion of heavy smokers (i.e. those who smoke more than 21 cigarettes per day) were found to be deviants regarding body type, hemogram, and blood circulation.

6. Greater deviation in cardiac function (i.e. RaV5, SV1 + RV5, and heart-lung ratio) was observed for those who drive a car and/or riding a motercycle.

The above results suggest that one's life habit such as exercise, occupation, smoking, and driving have an effect on his state of health including obesity, blood pressure, heartlung ratio from X-ray photograph, RaV5 and SV1 + RV5 from electrocardiograph, blood count, and biochemical test results of blood.

* 鹿屋体育大学健康教育学講座

* Department of Health Education, Kanoya National Institute of Fitness and Sports 


\section{I 目 的}

健康の保持増進には, 環境の改善努力が必要で あることは言うまでもなく, 誰もが承知の事実で ある。しかし，環境の一つである，われわれの生 活習慣の改善はきわめてむずかしいことも事実で ある。このような生活習慣は長い年月にわたり蓄 積されたものである。本研究は生活習慣が健康指 標に如何なる影響を及ぼすか否かについて検討す ることを目的として行った。

\section{II 方 法}

被検者は1987年 6 月 3 日から同年 9 月 22 日まで の約 4 力月間に打ける某健康管理センタ一健康診 査受診者 1,200 名である. 彼らの受診回数は初回目 が53.8\%，2回目が18.9\%であり，この合計で $72.7 \%$ 占めて扣り，頻回受診者ではない，女性 は割合がきわめて少なく，年齢の分散も大きいこ とから，除外し男性のみの955(79.6\%)名とした。 生活習慣は，運動，職業，乫煙，車の運転を取り 扱い，また健康指標には肥満度，血圧，胸部 X 線 撮影による心胸比，心電計によるRaV5および

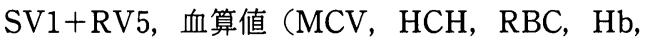
$\mathrm{Ht}$ ), 血液生化学的検查值 (ChE, $\gamma$-GTP, UA, T-Cho, $\beta$-LP, TG, HDL-Cho, FBS)を取り扱っ た。解析に当たっては表 1 に示した某健康管理セ ンターの正常域に準じて，健康指標の数量データ は質的データに変換してクロス集計，カイ 2 乗検 定による属性の関連性及び比率の差について検討 した。また，各属性間に执いて関連性の認められ たものの数量データについては $\mathrm{t}$ 值による平均值 の差の検定を行った。な技，本研究における被検 者の健康指標の平均值を表 1 に示した。

\section{III 結 果}

（1）各属性間の関連性

表 2 は被検者の生活習慣と臨床データとをク口 ス集計しそれらの関連性をみたもので，有意

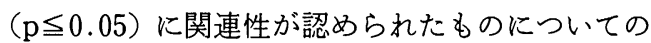
み示したものである。
表 1 健康指標の正常域及び被検者の平均值

\begin{tabular}{|c|c|c|c|c|}
\hline \multicolumn{2}{|c|}{ 健康指標 } & 正常域 & 平均値 & 単 位 \\
\hline \multicolumn{2}{|l|}{ 肥満度 } & $-10 \sim 10$ & 10.0 & $\%$ \\
\hline \multicolumn{2}{|l|}{ 心胸比 } & $50 \leqq$ & 46.1 & $\%$ \\
\hline \multirow[t]{2}{*}{ 血 王 } & 収縮期 & $100 \sim 150$ & 125.2 & $\mathrm{mmHg}$ \\
\hline & 払張期 & $60 \sim 90$ & 79.1 & $\mathrm{mmHg}$ \\
\hline \multicolumn{2}{|c|}{ 空腹時血糖値（FBS） } & $60 \sim 115$ & 100.1 & $\mathrm{mg} / \mathrm{dL}$ \\
\hline \multirow[t]{2}{*}{ 心電図 } & RaV5 & $2.6 \leqq$ & 2.2 & $\mathrm{mv}$ \\
\hline & SV1+RV5 & $4.0 \leqq$ & 3.3 & $\mathrm{mv}$ \\
\hline \multirow[t]{5}{*}{ 血 算 } & $\mathrm{RBC}$ & $400 \sim 550$ & 483.7 & $10^{4} / \mathrm{mL}$ \\
\hline & $\mathrm{Hb}$ & $13.8 \sim 18.0$ & 16.0 & $\mathrm{~g} / \mathrm{dL}$ \\
\hline & $\mathrm{Ht}$ & $40 \sim 50$ & 45.1 & $\%$ \\
\hline & $\mathrm{MCV}$ & $82 \sim 102$ & 93.9 & fl \\
\hline & $\mathrm{MCH}$ & $27 \sim 35$ & 33.1 & $\mathrm{pg}$ \\
\hline \multirow[t]{7}{*}{ 血生化 } & $\mathrm{ChE}$ & $0.6 \sim 1.2$ & 0.84 & $\Delta \mathrm{pH}$ \\
\hline & $\gamma$-GTP & $0 \sim 50$ & 36.9 & $\mathrm{mU}$ \\
\hline & UA & $2.5 \sim 8.0$ & 5.2 & $\mathrm{mg} / \mathrm{dL}$ \\
\hline & T-Cho & $130 \sim 250$ & 183.4 & $\mathrm{mg} / \mathrm{dL}$ \\
\hline & $\beta$-LP & $250 \sim 800$ & 560.9 & $\mathrm{mg} / \mathrm{dL}$ \\
\hline & TG & $50 \sim 150$ & 146.6 & $\mathrm{mg} / \mathrm{dL}$ \\
\hline & HDL-Cho & $35.0 \sim 80.0$ & 50.4 & $\mathrm{mg} / \mathrm{dL}$ \\
\hline
\end{tabular}

表 2 各属性間に打ける有意（ $\mathrm{p} \leqq 0.05 ）$ な関連性

\begin{tabular}{|c|c|c|}
\hline \multicolumn{2}{|r|}{ 生活習慣 } & 健康指標 \\
\hline \multirow[t]{2}{*}{ 運動 } & 有無 & 心胸比 \\
\hline & 動機 & FBS \\
\hline \multirow[t]{2}{*}{ 職業 } & 他者評価 & 肥満度, TG \\
\hline & 兼業の有無 & RaV5 \\
\hline \multirow[t]{2}{*}{ 乫煙 } & 有無 & $\begin{array}{l}\text { 肥満度, 収縮期血压, 抾張期血圧, } \\
\mathrm{RaV} 5, \mathrm{CV} \text {, }\end{array}$ \\
\hline & 1 日21本以上 & 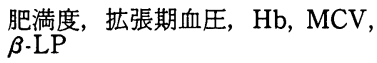 \\
\hline \multirow[t]{2}{*}{ 運転 } & 自動車 & SV1+RV5, MCH \\
\hline & 自動二輪車 & 心胸比, RaV5, SV1+RV5 \\
\hline
\end{tabular}

運動については，その有無は心胸比，動機は空 腹時血糖值に関連性が認められている。

職業については, その兼職の有無は RaV5に, 勤 労の他者評価は肥満度, TG に関連性が認められ ている.

契煙については，その有無が肥満度，最大血圧， 最小血圧, MCV, HCH, RaV5, HDL-Choに, 1 日の䝟煙本数は肥満度, 最小血圧, $\mathrm{MCV}, \mathrm{Hb}$, 
$\beta$-LPに関連性が認められている。

車の運転については自動車の場合が SV1+ RV5, MCH に, 自動二輪車が RaV5, SV1+RV5, 心胸比に関連性が認められている。

（2）有意関連属性における健康指標の比較

表 3 は各属性間において，有意に関連性が認め られたものの平均值を比較し, 有意 $(\mathrm{p} \leqq 0.05)$ に 差の認められたもののみを示したものである。す なわち生活習慣といら属性において，どちらの方 の生活習慣に拈いて高い値であるか, あるいは低 い値であるかを比較しようとするものである。

空腹時血糖値の場合, 運動の動機で楽しみのた めよりも健康のための方が高い値を示している $(\mathrm{p} \leqq 0.001)$.

肥満度, TGの場合は, 勤労の他者評価において 働きすぎを言われる方が高い值を示している $(\mathrm{p} \leqq 0.01)$.

表 3 生活習慣に打ける各種健康指標平均値の 比較 $(\mathrm{p} \leqq 0.05)$

\begin{tabular}{|c|c|c|c|c|c|c|}
\hline & & $\overline{\mathrm{X}}$ & S.D. & 比較 & $\overline{\mathrm{X}}$ & S.D. \\
\hline & 運動の動機 & \multicolumn{2}{|c|}{ 健康のため } & \multicolumn{3}{|c|}{ 楽しみのため } \\
\hline & FBS & 101.5 & 15.0 & $>$ & 96.3 & 15.1 \\
\hline \multicolumn{2}{|c|}{ 職業の働きすぎ } & \multicolumn{2}{|c|}{ 言われる } & & \multicolumn{2}{|c|}{ 言われない } \\
\hline \multicolumn{2}{|r|}{ 肥満度 } & 8.6 & 13.1 & $<$ & 11.1 & 12.5 \\
\hline \multicolumn{2}{|r|}{ TG } & 140.3 & 90.1 & $<$ & 158.1 & 92.3 \\
\hline \multicolumn{2}{|c|}{ 喫煙の有無 } & \multicolumn{2}{|c|}{ 有る } & & \multicolumn{2}{|c|}{ 無し } \\
\hline \multicolumn{2}{|r|}{ 肥満度 } & 8.4 & 13.7 & $<$ & 11.1 & 11.8 \\
\hline \multicolumn{2}{|r|}{ 収縮期血圧 } & 121.2 & 16.5 & $<$ & 126.1 & 17.5 \\
\hline \multicolumn{2}{|r|}{ 払張期血圧 } & 76.5 & 10.7 & $<$ & 80.0 & 11.4 \\
\hline \multicolumn{2}{|r|}{ RaV5 } & 2.1 & 0.7 & $<$ & 2.3 & 0.8 \\
\hline \multicolumn{2}{|r|}{$\mathrm{MCV}$} & 94.2 & 4.7 & $>$ & 92.2 & 3.8 \\
\hline \multicolumn{2}{|r|}{$\mathrm{MCH}$} & 33.3 & 2.0 & $>$ & 32.6 & 1.5 \\
\hline \multicolumn{2}{|c|}{ 喫煙数（1 日） } & \multicolumn{2}{|c|}{$1 \sim 20$ 本 } & & \multicolumn{2}{|c|}{ 20本以上 } \\
\hline \multicolumn{2}{|r|}{ 肥満度 } & 6.3 & 14.0 & $<$ & 10.4 & 13.6 \\
\hline \multicolumn{2}{|r|}{$\mathrm{Hb}$} & 15.8 & 1.4 & $<$ & 16.5 & 1.2 \\
\hline \multicolumn{2}{|r|}{$\beta \cdot \mathrm{LP}$} & 535.0 & 165.1 & $<$ & 590.9 & 220.3 \\
\hline \multirow[t]{6}{*}{ 運 } & 転 自動車 & \multicolumn{2}{|c|}{ する } & & \multicolumn{2}{|c|}{ しない } \\
\hline & SV1+RV5 & 3.2 & 1.0 & $>$ & 3.0 & 1.0 \\
\hline & 自動二輪車 & \multicolumn{2}{|c|}{ する } & & \multicolumn{2}{|c|}{ しない } \\
\hline & RaV5 & 2.2 & 0.8 & $>$ & 2.1 & 0.7 \\
\hline & SV1+RV5 & 3.3 & 1.0 & $>$ & 3.1 & 0.9 \\
\hline & 心胸比 & 46.1 & 4.3 & $>$ & 45.2 & 4.1 \\
\hline
\end{tabular}

$\mathrm{MCV}, \mathrm{MCH}$ の場合, 䝟煙において非契煙者よ

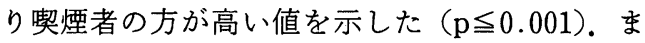
た, 肥満度, $\mathrm{Hb}, \beta$-LP は 1 日喫煙本数が 20 本以

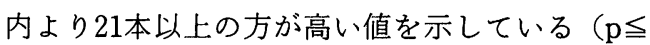
0.01 ).

SV1+RV5の場合は，車の運転において自動車 を運転しない方より運転する万が高い值を示した

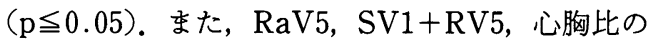
場合は自動二輪車を運転しない方より運転する方 が高い値を示している（ $\mathrm{p} \leqq 0.05 ）$.

（3）生活習慣における健康指標異常者の比較

表 4 は生活習慣のクロス集計に拉いて，どちら の生活習慣に某健康管理センタ一正常域に打ける 健康指標の異常者が有意 $(\mathrm{p} \leqq 0.05)$ に多いかを示 したものである。

運動において，心胸比は運動をしている方より していない方が，また，赤血球数，MCVはよくす る方よりあまりしない方が, 空腹時血糖值は楽し みのためより健康のための方が異常者の割合が高

表 4 生活習慣に打ける健康指標異常者の比 較 $(\mathrm{p} \leqq 0.05)$

\begin{tabular}{|c|c|c|c|}
\hline \multirow{3}{*}{$\frac{\text { 生活習慣 }}{\text { 運動の有無 }}$} & \multirow{3}{*}{\begin{tabular}{l}
\multicolumn{1}{c}{ 健康指標 } \\
心胸比 \\
FBS
\end{tabular}} & \multicolumn{2}{|c|}{ 異常者の比較 } \\
\hline & & 有る & <無し \\
\hline & & 健康のため & つ>楽しみのため \\
\hline \multirow[t]{2}{*}{ 職業の働きすぎ } & 肥満度 & 言われる & <言われない \\
\hline & TG & 言われる & く言われない \\
\hline \multirow[t]{7}{*}{ 喫煙の有無 } & 肥満度 & 有る & <無し \\
\hline & 收縮期血圧 & 有る & <無し \\
\hline & 执張期血圧 & 有る & <無し \\
\hline & RaV5 & 有る & <無し \\
\hline & $\mathrm{MCV}$ & 有る & $>$ 無し \\
\hline & $\mathrm{MCH}$ & 有る & $>$ 無し \\
\hline & HDL-Cho & 有る & $>$ 無し \\
\hline \multirow[t]{5}{*}{1 日の䝟煙本数 } & 肥満度 & 1 20本 & $<21$ 本以上 \\
\hline & 执張期血圧 & $1 \sim 20$ 本 & $<21$ 本以上 \\
\hline & $\mathrm{Hb}$ & $1 \sim 20$ 本 & $<21$ 本以上 \\
\hline & $\mathrm{MCV}$ & $1 \sim 20$ 本 & $<21$ 本以上 \\
\hline & $\beta$-LP & $1 \sim 20$ 本 & $<21$ 本以上 \\
\hline \multirow[t]{2}{*}{ 自動車の運転 } & SV1+RV5 & する & >しない \\
\hline & $\mathrm{MCH}$ & する & くしない \\
\hline \multicolumn{2}{|c|}{ 自動二輪車の運転 RaV5 } & する & >しない \\
\hline & SV1+RV5 & する & >しない \\
\hline & 心胸比 & する & >しない \\
\hline
\end{tabular}


い傾向にある。

肥満度，TGは働きすぎと言われる方より言わ れない方が，RaV5は兼職の有るものの方が異常 者の割合が高い傾向にある.

$\mathrm{MCV}, \mathrm{MCH}, \mathrm{HDL}-\mathrm{Cho}$ は非掣煙者より契煙者 の方が, 肥満度, 最大血圧, 最小血圧, RaV5は非 契煙者の方が異常者の割合が高い傾向にある。 た, 最小血圧, MCV は21本以上の契煙者より 20 本 以下の方が，肥満度， $\mathrm{Hb}, \beta-\mathrm{LP}$ は21本以上の方 が異常者の割合が高い傾向にある。

$\mathrm{SV} 1+\mathrm{RV} 5$ は自動車を運転しない方より運転す る方が，MCV は逆にしない方が異常者の割合が 高かった。また, RaV5, SV1+RV5, 心胸比は自 動二輪車を運転する方が異常者の割合が高い傾向 にある。

\section{IV 考察}

生活習慣が健康に及ぼす影響については，健康 診査の受診回数, 運動の継続，契煙など多くの報 告がある. 本研究ではこれら以外の職業, 仕事に 対する他者評価，近年の車社会を取り扱った。 た，被検者はすべて男性であり性的特性による交 絡因子は除外されるが，結論は男性のみに限定さ れる.ささらには健康管理センターの 1 から 2 回以 上の検診受診者であることから，健康意識はさほ ぞ低くはなく，未調查ではあるが経済的にも裕福 であると思われる，彼らの年齢分布は50歳台にそ のピークがあり，平均年齢とほぼ一致し約50歳で ある．職業は $60 \%$ 以上が農業関係者である，従っ て, 地域の生活習慣が強く表現され，偏った結論 を導き出す可能性もあるが，その点については極 力注意した。

運動は心胸比, 空腹時血糖值に関連していたが, 心胸比は運動の有無や動機間での比較においては 有意な差は認められていない，ところが心胸比の 異常者は運動をしていない方に多かった。このこ とに関しては，逆に運動を継続して行うことによ り心肥大 (スポーツ心臓) が起こるとする川原の 報告がある．彼の報告によると，スポーツ心臓は 病的心臓のように顕著に拡大するものではなく,
心胸比でみると $50 \%$ 以下が殆どであるとするもの である，従って運動をしていない彼らの心肥大は スポーッ心臓ではなく，むしろ心肥大があるため に運動ができないでいる可能性もある。ところが， 本研究で用いた運動には，被検者はラジオ体操の ような軽いものからジョギングのようなきわめて 激しい運動までを捉えている可能性があるために 心肥大とスポーッ心臓との関係については明確に 論じ得ない，従って，運動レベルの明確化は今後 の検討課題としたい.

職業においては, 他者評価は肥満度, TGに関連 性が認められた。そして働きすぎと言われる者は 肥満度, TGが高い傾向を示した。これは働きすぎ ることにより消費エネルギーが高くなるために瘦 身化してくると考学る方が一般的であろう．しか し，一方では他者評価による働きすぎの人々は摂 食も旺盛なために肥満傾向にあるが異常状態では ないとも考えられる，本研究では，働すぎと言わ れない者には肥満症や高脂血症が多い傾向にあっ た。このように，働きすぎと言われない人々にむ しろ異常者が多く, 彼らは, 肥満症や高脂血症が あるために働さすぎることがでさない状態にある 可能性も考えられる.

兼職は，心胸比には関連性を認めなかったが， RAV5とは関連性が認められた。すなわち, 兼職す ることによる仕事量の増大や，それに伴らストレ スなどが心蔵にかなりの負担を加えているための ものと考えられる。

契煙習慣が及ぼす健康影響についての報告は多 い. 本研究では非笫煙者は契煙者に比べて肥満が 高くなる傾向がみられた。これは契煙によるェネ ルギー消費の増大が肥満への抑制につながってい る可能性がある，しかし，猰煙者に限定するなら ば，契煙本数が増加するに伴い肥満症が多くな る傾向を示した。このことは頻度の高い契煙行動 と共に摂食行動も増加していることが推定され る。つまり嗜癖であり，脅迫性格を背景にした心 理的因子の関与が大きいことが考えられる.三河 ら，小澤らは契煙量と最小血圧との間には有意な 負の相関が認められ, 喫煙量が多いほど最小血圧 
は下がる傾向を示すと報告している，本研究では 非契煙者の方がいずれの血圧ともに高く, 高血圧 者の割合も高かった。この原因としては第 1 に二 コチンの薬理作用, 第 2 に契煙による心理的リラ クゼーション効果, 第 3 にリスファクターであ る喫煙ができない心理的, 社会的, 身体的状況が 考えられる. 第 1 のニコチンは血管収縮作用, 昇 圧作用があることが実験的に証明されており，本 質的原因としては説明し得ない。従って第 2 ある いは第 3 による原因の可能性が高いものと考えら れる。

本研究では上述以外に打いても㔖煙との様々な 関連性が認められた。すなわち非契煙者に比べて 契煙者の方がRaV5が低くなり，かつ MCV, $\mathrm{MCH}$ が多くなる傾向が認められたり，一般的ス モーカー（1 日20本以下）に比べてへビースモー カー（ 1 日21本以上）の方が $\mathrm{Hb}, \beta$-LP が多く, $\mathrm{MCV}$ が少なくなる傾向が観察されている，例え ば，ここでの $\mathrm{Hb}, \mathrm{MCH}$ が増加した原因がニュチ ンによる直接的な薬理作用であるのか，あるいは 頻度の高い契煙といった行動様式に起因するかは 不明である.これらのことに関連して, 最近 H.E. Eysenk は肺癌や冠動脈疾患は製煙それ自体とで はなく，契煙を好む性格と相関関係にあると発表 している.このことはすなわち癌や冠動脈疾患に なりやすいパーソナリティがあり，そのパーソナ リティを有している人々が笫煙を好むのだといら 考えであろら。

近年, わが国の日常生活習慣は車社会と言われ るほどに, 多くの人々の生活習慣を変貌させてい る。このような社会での健康影響についても見逃 し得ない因子の一つと思われる. 本研究では自分 で運転する自動車及び自動二輪車を取り上げた。 これらは心機能に関連し, 運転する方に異常者が おおい傾向を認めた。このことは，乗り物を運転 することが心蔵への負荷因子となり，心機能が異 常こう進される可能性も考えられる. 故に, 車社 会は心臓にストレスを加え, 心肥大や心機能異常 を招いている可能性も否定できないものと考兄 る.

\section{V 結 語}

本研究は生活習慣が健康に影響を及ぼすか否か について検討することが目的である。被検者は 1987 年 6 月 3 日から同年 9 月 22 日までの約 4 カ月 間に打ける某健康管理センタ一健康診査受診者 1,200名のうち，男性のみの955（79.6\%）名であ る. 彼らの運動や職業などの生活習慣と臨床検査 に损ける健康指標を検討項目として解析した。そ の結果，

（1）生活習慣としての職業, 㔖煙, 車や自動二 輪車の運転は，様々な健康指標と関連性が認めら れた.

（2）運動の目的が健康の場合は空腹時血糖値 に，運動をしないものは心胸比，赤血球数, $\mathrm{MCV}$ に異常者の割合が高い傾向にあった。

（3）働きすぎといわれる者は肥満度， TG(トリ グリセライド）が有意な高値を示したが, 異常者 の割合は低い傾向にあった。

(4) 兼職は心臓機能 (RaV5) の異常割合が高い 傾向にあった。

（5）へビースモーカー（1 日21本以上制煙者） は体型, 血液像, 血液循環などの異常割合が高い 傾向にあった。

（6）自動車及び自動二輪車の運転は心臓機能 （RaV5，SV1+RV5，心胸比）の異常割合が高い 傾向にあった。

以上のことから, 運動, 職業, 妿煙, 車の運転 などの生活習慣は肥満度, 血圧, 胸部 X 線撮影に よる心胸比, 心電計による RaV5および SV1+ RV5, 血算值, 血液生化学的検查值なぞの健康指 標に様々な影響を及ぼしていることが示唆され た.

本稿を終るに当たり，また本研究に際し並々ならぬ ご協力をいたたいた鹿児島県厚生連健康管理センター の中馬，上釜の両氏をはじめ，保健婦，並びに職員の 皆様に対し深謝の意を表する。

\section{文献}

浅野勝巳（1985）：運動実施と中高年者の呼吸循環機 
能, 体育の科学, 30, 803-811

浅野牧茂(1982)：乫煙, 内科雑誌 Medicina, 19, 1436 $-1438$

東あかね, 他 (1986)：健康診断継続受診者の特性一問

診, 判定結果の検討一, 日本衛生学雑誌, 41,287

井川幸雄(1982)：運動, 内科雑誌 Medicina, 19, 1430 $-1431$

井川幸雄，他（1983）：運動の習慣化の要因及び習慣

的運動の効果に関する研究, 体育科学, 11, 177-183

片岡幸雄，他（1983）：身体トレーニングが高血圧症 の改善に及ぽす効果に関する研究（第 3 報）一高血 圧症改善のための運動条件の検討一, 体力研究, 55 , $41-54$

片岡幸雄, 他 (1985)：中高年高血圧者の長時間ラン ニングに伴う血圧変動, 体力研究, $60,13-24$

川原 貴 (1984)： スポーッ心と病的心, Japanese Journal of Sports Sciencesm 3(1), 37-43

木村みさか (1987)：血清脂質パターンに良い影響を もたらす運動習慣の検討（食生活及びその他の生活 習慣との関連で), 日本公衆衛生雑誌，42, 437

北村季軒（1984）：運動の習慣化に影響する要因につ いての検討一人間ドックを受検した大学教職員の実 態調査から一, 体育科学, $12,193-200$

北村季軒 (1985)： 運動習慣の有無別にみた中高年者 の血清脂質について，体育科学，13，185-190

今野広隆, 他 (1985)：歩行トレーニングが高血圧症 改善に及注す効果, 体力科学, 34,474

三河一夫, 他 (1986)：乫煙が血圧, 血清脂質, 肥満 度に与方影響, 日本公衆衛生雑誌，33，400

南谷和利 (1986)： スポーツ心臓, 臨床スポーツ医学, $3(1), 87-95$

三澤京子, 他(1987)：HDL-コレステロールと肥満及 び契煙について，日本公衆衛生雑誌，42, 296

森あき久，他（1987）：コレステロール值と肥満䒜煙 领酒との関係，日本公衆衛生雑誌，34, 401

中川哲也（1983）：心理的ストレッサー，医学のあゆ み, $125,321-325$

中川哲也（1985）：生涯各期に抢ける心身症をめぐる
諸問題，中年期（更年期），心身医学，25, 102

中井吉英, 他 (1985)：中年期に拈ける心身症の発症 要因としての生活習慣（㪘好品）とライフスタイル の検討, 心身医学, 25, 104-112

中本康朗, 他 (1986)：䒜煙と循環器疾患. 第 1 報。 契煙, 飲酒習慣と肥満度との関連, 日本公衆衛生雑 誌, 10,403

折茂 肇（1980）：HDL-コレステロールに影響を及 ぽす因子一運動，アルコール，タバコ，ホルモンそ の他一, 治療, 62(11), 83-88

小澤秀樹, 他 (1986)：喫煙と循環器疾患. 第 2 報。 㔖煙習慣が血圧に及ぼす影響，日本公衆衛生雑誌， 10,404

Eysenk H.J. (1987): Proceedings of Seminar on Behaviour Research and Therapy, The Japanese Association of Behaviour Therapy, 41-44

佐野忠弘（1985）：長期 aerobic 運動処方実践による 糖・脂質代謝 - 肥満の改善と運動強度 ・ 頻度 ・ 期間 との関係, 体力科学, $35,47-52$

澤井廣量 (1983)：高血圧と身体運動, 体育の科学, $28,444-447$

進藤宗洋, 他 (1985)：高血圧症と運動, 体育の科学, $35,189-196$

杉下靖朗(1985)： スポーツ心臟, 体育の科学, 30,789 $-802$

鈴木仁一 (1983)：ストレスと循環器疾患, 医学のあ ゆみ， 125(5), 412-417

高岡郁夫(1985)：脂質代謝とスポーツ，体育の科学， $35,260-265$

田辺信太郎 (1982)：ライフスタイルと健康問題, 体 育の科学, 32, 523-527

富永祐民（1987）：䝟煙と健康，公衆衛生，51，650 $-654$

柳橋次雄, 他（1988）：鹿児島姶良町住民の血圧値に 及ぼす各種生活要因の影響, 民族衛生，54, 83-91 吉田勝美（1987）：㚙煙の諸問題一功罪を含めて一, 健康管理, 2, 4-14

（受稿 1988．10．27） 